\title{
Transformation of the Big Narrative
}

\author{
When the Imperial Is Already Out, \\ but the National Is Not Yet In
}

Andrei A. Teslya

\begin{abstract}
One of the key issues on Russia's current and long-term political agendas is whether Russian identity is possible without Ukraine. The purpose of this article is to study the issue through a possible transformation of the "big narrative" in Russian history. An analysis of "big narratives," a practice established in the $1970 \mathrm{~s}-80 \mathrm{~s}$ in the continental research tradition, combines historical, philosophical, and sociological approaches. Russia's big historical narrative is essentially imperial, which implies that Ukraine is not an indispensable constitutive element with a preset value. Therefore, in this narrative "Russianness" has no fundamental relation to the issue of Ukraine. An alternative approach towards creating a big Russian narrative as a national one suggests that it is in conflict with the Ukrainian narrative since both seek to embrace the same groups and territories. In the long term, the prevailing imperial narrative will most likely include as its essential element the interpretation of the current state as "a decline of the empire" and a "loss," while the probability of its successful radical transformation now looks fairly low.
\end{abstract}

Key words: National identity, historical politics, historiography, big Russian narrative, Ukrainian national narrative, "large Russian nation"

Andrei A. Teslya, Ph.D. in Philosophy, is a Senior Research Fellow with the Academia Kantiana at Immanuel Kant Baltic Federal University, Kaliningrad, Russia.

SPIN РИНЦ: 616154

ORCID: 0000-0003-2437-5002

ResearcherID: E-9127-2015

mestr81@gmail.com

DOI: 10.31278/1810-6374-2018-16-2-68-76 
rimarily, the present research is based on my professional interest in the history of public thought in the Russian Empire

at the end of the nineteenth and the beginning of the twentieth centuries. This explains the choice of research instruments and the range of issues that formed the focus of analysis, while others appeared to be beyond its scope. This work is not meant to give a full and precise description of modern problems or provide a deep insight into them. Its purpose is to find out whether Russian identity is possible or impossible without Ukraine and what it looks like from the research perspective.

It is common knowledge that self-construction of a subject (or a political entity) is formed through description and self-description (At the individual level this is done using personal references and autobiographies created as part of office record-keeping (Kharkhordin, 1999)). Thus, in order to answer the original question, it is necessary first to briefly outline the existing Ukrainian and Russian models of placing oneself in historical time.

\section{THE "SHORT" AND "LONG" HISTORY OF UKRAINE}

The Ukrainian "framework" has two main formats. One is "short" and can be found in the History of Russians (the end of the 1810s and the beginning of the 1820s) and in the well-known interpretation by Nikolai Kostomarov (1817-1885), who traces Ukraine's history back to the sixteenth century and largely associates it with Cossacks. The other framework proposed by Vladimir Antonovich (1834-1908) and his disciple Mikhail Grushevsky (1866-1934) refers to much older times and directly opposes the "standard" scheme of Russian history (Plokhy, 2005).

What makes the first framework distinct is that it only slightly disagrees with the generally accepted scheme of Russian history. But its weak point is the lack of historical depth in studying the origins of the national historical canon. Ukrainian history appeared to be chronologically "short" to cover only the last several centuries, and was centered primarily on the Dnieper region (Plokhy, 2012; Tolochko, 2012). This approach made it possible to link confessional identity 
with national identity and portray the Bogdan Khmelnitsky uprising as a key national historical event, interpreting it as a "religious war" and the struggle for faith. But this created two complications.

On the one hand, there is no way to describe Ukraine as an antagonist of Great Russia in the main event of Ukrainian history. On the contrary, accession to the Moscow state looked like a logical and legitimate result of "unification" based on common faith as a key factor. Other factors such as linguistic closeness, a shared past, etc., were of secondary importance, just as the differences-cultural, political, etc.-appeared to be less important than fundamental unity. On the other hand, religious differences (Greek Catholic and Orthodox) complicated the incorporation of entire communities within "imaginary Ukraine," above all, Galicia. In addition, such a late "beginning" of Ukrainian history made it difficult to portray the whole "imaginary" space as an integral object of description.

The "long" version of Ukrainian history solved all these problems and became more preferable for the Ukrainian national movement. "Cossack" history was included in it as a period of "national revival," as a "return into history" with regard to Kievan Rus' described as the "Golden Age." This made it possible to use imaginary constructs that had already been created as part of other historical narratives. In other words, the task appeared to be much easier-national appropriation of existing symbols rather than creating new ones.

Both the "short" and the "long" versions of Ukrainian history, although presented differently with regard to the imperial historical framework (the former allows fairly painless "incorporation," while the other strongly opposes it), suggest the possibility of autonomous existence, which let us regard them as versions of the national narrative. But neither names the "hostile other," especially the "long" version. The "short" version, which links the national whole to confessional affiliation, has to use other faiths-Roman Catholicism, Judaism, Islam-as the ontological enemy. The "long" version of national history does not presuppose a mandatory "enemy." It can be any entity that opposes Ukraine's national goals and objectives or that makes them difficult to attain. So, this is a situational rather 
than ontological definition which makes it possible to change the status of subjects as "friends or foes" throughout history, depending on the situation. Over long stretches of time, one and the same entity can be an enemy at one moment and an ally at another, or become completely irrelevant.

\section{IMPERIAL NARRATIVE VS. THE RUSSIAN NATIONAL}

At the end of the seventeenth century, when Innokenty Gizel (c. 1600-1683) wrote his Synopsis (1674), the Russian narrative was essentially imperial in nature. In fact, it remains so today. Major changes occurred in the historical framework in the 1830s when the concept of a large Russian nation was developed, prompted on the one hand by the rise of European nationalism (the empire's attempts to assimilate the nationalist agenda formalized in the doctrine of an official nation), and on the other hand, by the need to incorporate into the integral historical narratives new communities which the empire had acquired after the division of the Polish-Lithuanian Commonwealth (into northern and southwestern provinces). Claims to these territories within the "large Polish nation" became manifest in the 1820s and grew particularly strong because of the Polish Uprising of 1830-1831.

As a result, a concept developed by Nikolai Ustryalov (1805-1870) prevailed as a common framework. He suggested dividing Russian history into ancient history and modern history. The former split up the original unity into the history of Eastern and Western Rus to merge them together into the Russian Empire, politically at first and eventually religiously in 1839 after the abolition of the Union of Brest in 1596. The imperial framework proposed by Ustryalov was based on confessional unity. The empire appeared as an "Orthodox kingdom," with its current state (as seen by the author) being the highest point with regard to the past and the historical result of the previous development and proper embodiment of the original unity. But the history of Western Russia was interpreted as equal to that of Eastern Rus', and both flows then merged together into the river of imperial history (Teslya, 2015: 725-737). 
However, in practice this historiographical scheme was rarely applied so harmoniously. The prevailing approach largely continued the previous tradition (dating back to Gizel and continuing up to Karamzin through Tatishchev and Shcherbatov) and was based on the synthesis of the history of commonness ("Russian") and the history of dynasties. It emphasized the history of Northeastern Rus' as part of the "translation of thrones" (similar to the "translation of empire") from Kiev to Vladimir, and then to Moscow and St. Petersburg. The History of Russia Since Ancient Times (in twenty-nine volumes published in 18511879) written by Sergei Solovyov (1820-1879) is a vivid example of this scheme codified by him in text (all the more influential as Solovyov created a number of texts intended for the general public and schools). The focus is on the single history of state power from Novgorod to Kiev and St. Petersburg. The narrative follows the abovementioned "translation of thrones," while other episodes are highlighted only in relation to the first one. For example, the history of southern Russia is covered retroactively in connection with the incorporation of Little Russia to explain the processes that had eventually brought these lands under Moscow's control.

The "demobilization" version of the imperial narrative was to some extent presented by Vassily Klyuchevsky (1841-1911) in his Course of Russian History, where the focus shifted from the history of power to the history of people and society, primarily that of Great Russia. The history of Russia is interpreted as the chronicles of a colonized country that was acquiring its historical image through economic development directed by the grassroots initiative subsequently picked up and formalized by the state. But as Klyuchevsky's closest contemporaries and followers pointed out, he did not create a historical concept as such. Instead, he used his teacher Sergei Solovyov's scheme, scrapping certain parts of it and sometimes changing its focal points significantly, but he did not offer a cohesive alternative (Shahanov, 2003).

The Soviet historical framework, created in the late Stalinist period (1938-1953) after the turmoil of the first two decades, largely reproduced the imperial scheme inherited from Solovyov and 
Klyuchevsky, who once again were proclaimed classics of Russian history. The "history of the Soviet Union" was based on two principles. The first was the projection of existing borders (reflected among other things in the peculiar name of study courses, such as the "History of the Soviet Union Since Ancient Times," which in turn was copied from Solovyov's work). The second was that the history of political power had become the cementing element, requiring an appropriate interpretation of the history of peoples living in the Soviet Union, which dated back to the moment when each of them had joined the imperial whole, with a more or less detailed look into the past up to the moment of incorporation. The subsequent narrative fitted into the general chronology.

Today the prevailing scheme of Russian history continues the imperial and Soviet historiographical tradition, but has lost both the ideological core, which was characteristic of the pre-revolutionary imperial history, and the logic of the common Soviet narrative. Both are teleological and triumphalistic in nature and portray the present as the result and purpose of the preceding periods, while at the same time presage a much better future.

The history of the "large Russian nation" was the core of the prerevolutionary imperial narrative. The nation itself was imperial, with all other communities and territories relegated to an object of possession, domination, or mutually advantageous alliance. In later versions, this commonness appeared as a historical entity correlated with the political entity-an empire as a representation of the former (paraphrasing Gustav Shpet, this is a substantialist construct: "an empire and its owner"). The Soviet construct was built as an ideocratic one, but envisaged a national hierarchy. The place of the "large Russian nation" was taken by "three brotherly [East] Slavic peoples," with a common Soviet imperial history presented as the history of Russians.

In other words, if the existing historical narrative is maintained, the modern history of Russia will inevitably become "the history of losses" and the "history of defeats." On the one hand, this narrative feeds revanchism, while on the other hand it fuels a desire in con- 
crete communities to separate from this whole and find their own versions of identity that will allow them to build a positive image of the future; a history of success, not decline. The historiographical experience of Russian nationalists, particularly Sergei Sergeyev's Russian Nation (2016), is such an attempt. Sergeyev views the Russian nation as a victim of the empire, and describes its history as a series of trials and tragedies which give it a moral right to claim superiority and at the same time offer hope for its own national project (Sergeyev, 2017).

Conceptual difficulties are best seen in various interpretations of (including differing official statements on) the incorporation of Crimea. Either this is an act of partial imperial revenge, a return of the empire that is again beginning to bring the outlying space under its control after a period of maximum weakness; or this is a reunification based on the logic of "Russianness" (linguistic or ethnic as in some nationalistic rather than official interpretations), that is, not "a continuation" of the previous imperial history, but one of the key events in the history of "Russia," which is somehow separated from the historical imperial narrative. Therefore, it means more or less explicitly the interpretation of "Russia's history" as a separate part of the history of the Russian Empire. In this case Russia becomes an object that can either be found within the "big" imperial history or, considering the current situation, is a multitude which becomes "tangible" after acquiring a lower or higher degree of personality as it did in 1918, 1990, and 1991. So, the logic underlying the development of this multitude can be traced retroactively into the past, revealing the "genealogy" model at work.

\section{IMPERIALNESS OF ANOTHER LEVEL}

Is Ukraine necessary and indispensable for Russia's self-description and self-understanding? Can Russia be imagined without Ukraine? Considering the abovementioned historical background, the imperial framework alone does not envisage Ukraine as a necessary element. Moreover, the imperial construct, being essentially dynamic, contains no territorial or historical elements as something indispensable (as 
borne out by the very logic of the "translation of empire"). Interestingly, neither of the two key versions of the Ukrainian national historical narrative contains Russia as a substantial element or as "an enemy."

On the contrary, Russia's national identity is in deep conflict with the Ukrainian national narrative in any of its forms, as it claims part of the imaginary national community which is constitutive for Ukraine. A conflict with Ukraine is part of the efforts to build a national whole through the image of enemy and national mobilization, using the "negative identity" model.

But the actual problem of Russian identity lies elsewhere. It requires the ability to radically change the imperial narrative and offer a different version of imperial history that would be based on the logic of the present historical community rather than on the bygone one. It is necessary to block revanchist threats and/or modify the perception of Russia as a co-heir of the Russian Empire, as part of the large imperial space. In other words, it is necessary to single out in the large historical narrative an episode about Russia that would have its own logic.

A major difficulty in doing this is caused by the need to refer to the transcendental which is characteristic of the imperial whole. Unlike a national community, an empire presupposes a universal principle of unification which cannot be used for addressing pragmatic issues (Filippov, 2014). The imperial whole can exist for a rather long time by inertia with the "transcendental cutoff." Established ties and customary ways of self-identity often outlive the logic upon which they were initially based and can even serve (like what happened to the Soviet Union with regard to the Russian Empire) as the basis for constructing new meanings that would sophisticatedly modify the original ones. But for the new meanings to emerge, there must be a different imperial vision based on a combination of resources, goals, and inspiring power of action supported by concrete results. However, the possibility to set different goals going beyond pragmatic purposes and changing the very framework of pragmatic action raises the biggest doubts in the current situation, whereas an inertia-driven scenario is dominated by the logic of losses and partial restorations, with all the ensuing consequences. 
Andrei A. Teslya

\section{References}

Filippov, A.F., 2014. Sociologia. nablyudeniya, opyty, perspektivy. Vol. 1. St.-Petersburg: Vladimir Dal.

Kharkhordin, O.V., 1999. The collective and the individual in Russia: A study of practices. Berkeley and Los Angeles: University of California Press.

Plokhy, S.N., 2012. The Cossack myth: history and nationhood in the age of empires. Cambridge University Press.

Plokhy, S.N., 2005. Unmaking imperial Russia: Mykhailo Hrushevsky and the writing of ukrainian history. University of Toronto Press.

Sergeev S.M., 2017. Russkaya naciya, ili rasskaz ob istorii eyo otsutstviya. Moscow: Centrpoligraf.

Shahanov A.N., 2003. Russkaya istoricheskaya nauka vtoroj poloviny XIX nachala XX veka. Moskovskij i Peterburgskij universitety. Moscow: Nauka.

Teslya, A.A., 2015. Posledniï iz 'ottsov': Biografiia Ivana Aksakova. St.-Petersburg: Vladimir Dal.

Tolochko, A.P., 2012. Kievskaya Rus i Malorossiya v XIX veke. Kiev: Laurus. 